\title{
Quantitation Over Time of Tomato Yellow Leaf Curl Geminivirus DNA in Its Whitefly Vector
}

\author{
P. Caciagli and D. Bosco
}

First author: Istituto di Fitovirologia Applicata, CNR, Strada delle Cacce 73, 10135 Torino, Italy; second author: Di.Va.P.R.A.-Entomologia e Zoologia applicate all' ambiente, University of Torino, Via L. da Vinci 44, Grugliasco (To), Italy.

Accepted for publication 19 February 1997.

\begin{abstract}
Caciagli, P., and Bosco, D. 1997. Quantitation over time of tomato yellow leaf curl geminivirus DNA in its whitefly vector. Phytopathology 87: 610-613.

The amount of tomato yellow leaf curl geminivirus (TYLCV) DNA that accumulated in the vector Bemisia tabaci was studied by quantitative chemiluminescent dot-blot assay, using digoxigenin-labeled specific DNA probes. Large groups of female whiteflies were allowed to feed for $4,12,24$, or $48 \mathrm{~h}$ on TYLCV-infected tomato plants and then were transferred to TYLCV-immune cucumber plants. Insects were sampled at

on the head plus prothorax (to include salivary glands) and abdomen separately. The maximum amount of TYLCV DNA, averaging from 0.5 to $1.6 \mathrm{ng}$ per insect, was always attained at the end of the acquisition period. The mean amount then decreased by about 1 to $2 \%$ per day, remaining clearly detectable up to 20 days after the end of the acquisition period. Only some whiteflies that were TYLCV-positive in the abdomen were positive for head plus prothorax. In both parts of the body, TYLCV DNA remained detectable up to 18 days after the end of the acquisition period, showing that TYLCV DNA remains in insect tissues much longer than infectivity indicates.
\end{abstract} different times during and after acquisition access and tested for TYLCVDNA content. TYLCV-DNA assays were done either on whole insects or

Tomato yellow leaf curl virus (TYLCV), a whitefly-transmitted monopartite geminivirus, causes severe disease of tomato $(4,6)$. The possible replication of two isolates of TYLCV in the vector Bemisia tabaci Gennadius of the B biotype (also known as the silverleaf whitefly, B. argentifolii) (14) has been suggested (12,13). These works were based on detection of TYLCV DNA in groups of vectors at increasing times after a short acquisition access period (AAP). Previously, Cohen et al. (3) reported data suggesting possible replication of squash leaf curl virus (SLCV), a bipartite geminivirus, in B. tabaci. Recent findings of cytopathological effects of SLCV in its vector also support this hypothesis (15).

The DNA genome for an isolate of TYLCV from Sardinia, Italy (TYLCV-S) $(8,11)$, has been cloned and sequenced (10), and its relationships with a Sardinian population of $B$. tabaci have been studied in detail (2). We report here the results of measuring levels of TYLCV DNA in whole and in parts of individual insects at various times after acquisition of TYLCV to test for a possible increase of TYLCV DNA in the insect vector after the end of the AAP.

\section{MATERIALS AND METHODS}

Handling of virus and insects. TYLCV-S originally was isolated from infected tomato plants (Lycopersicon esculentum Mill.) from greenhouses in Sardinia and maintained in the greenhouse by transmission with its whitefly vector B. tabaci. B. tabaci from Sardinia (B biotype) were reared on cucumber plants (Cucumis sativus L. 'Marketer') immune to TYLCV (5). Insects collected from cucumber rearing plants will be referred to as nonviruliferous. Trialeurodes vaporariorum Westwood whiteflies were reared

Corresponding author: P. Caciagli; E-mail address: caciagli@ifa.to.cnr.it

Publication no. P-1997-0403-01R

(C) 1997 The American Phytopathological Society
Additional keywords: dot-blot hybridization. on Nicotiana tabacum L. 'White Burley' plants. Handling of plants and vectors was as described by Caciagli et al. (2). Only female whiteflies were used for this work, because preliminary experiments showed that females acquire more virus in less variable amounts than males (data not shown). Experimentally infected tomato cv. Marmande plants served as the TYLCV source.

Short AAP experiments. (i) Nonviruliferous B. tabaci were allowed $4 \mathrm{~h}$ of acquisition access to virus-infected plants and then were transferred to cucumber. Samples (groups of insects) were taken before acquisition (nonviruliferous controls), at the end of the AAP, and $20 \mathrm{~h}$ after transfer to cucumber. As a further control, a comparable number of $T$. vaporariorum, a whitefly nonvector of TYLCV, was treated in the same way. Shoots with symptoms from the same plants were offered at the same time to the two whitefly species. (ii) Nonviruliferous B. tabaci were allowed $12 \mathrm{~h}$ of acquisition access to TYLCV-infected plants and then were transferred to cucumber. Samples were taken before acquisition (controls), at the end of the AAP, and 12, 24, and $36 \mathrm{~h}$ after the end of the AAP (transfer to immune plants).

Increasing AAP experiments. (i) Nonviruliferous $B$. tabaci were allowed access to TYLCV-infected plants for $24 \mathrm{~h}$ and then were transferred to immune plants. Samples were taken before the start of acquisition, after $4,8,12$, and $24 \mathrm{~h}$ of acquisition access, and 24, 48, and 72 after transfer to immune plants. (ii) Nonviruliferous B. tabaci were allowed access to TYLCV-infected plants for $48 \mathrm{~h}$ and then were transferred to immune plants. Samples were taken before the start of acquisition and after $4,8,12,16,24$, and $48 \mathrm{~h}$ of acquisition access. After transfer to cucumber, samples were taken every $24 \mathrm{~h}$ for 9 days and then 20 days after the transfer ( 22 days after the start of the AAP).

All insects from these experiments were killed with carbon dioxide and frozen individually at $-20^{\circ} \mathrm{C}$ in microplates (round bottom wells) with $20 \mu \mathrm{l}$ of TE buffer $(10 \mathrm{mM}$ Tris-HCl, $1 \mathrm{mM}$ $\mathrm{Na}_{2}$ EDTA, pH 8.0). When needed for assay, insects were thawed and disrupted manually with a needle under a stereomicroscope 
and homogenized in an ultrasonic bath, at $24 \mathrm{kHz}$, for $20 \mathrm{~min}$ in the original plate. Finally, $80 \mu \mathrm{l}$ of TE buffer was added to each well.

Viral DNA in dissected insects. Nonviruliferous B. tabaci were allowed a 24-h AAP on TYLCV-infected plants and then were transferred to immune plants. Samples were taken before the AAP, at the end of the AAP, and 1, 4, 7, 11, 14, and 18 days after the end of the AAP. Insects were killed with carbon dioxide and dissected under a stereomicroscope with sterile needles. The head plus the first segment of the thorax were separated from the rest of the body (second and third thoracic segments plus abdomen). The two parts were frozen separately and treated as for whole insects. The prothorax was included with the front part of the insect to separate all salivary glands from the rest of the body (9).

Quantification of viral DNA in whole and dissected insects. TYLCV DNA was detected with digoxigenin-labeled probes and quantified by measuring the optical density of films exposed to chemiluminescent dot blots on nylon membranes (1). To calibrate each membrane, two series of seven known amounts of either pTY-DIM plasmid containing TYLCV DNA or purified TYLCV virions in TE buffer and the buffer itself were used. X-ray films exposed to membranes were analyzed with a 300A computing densitometer equipped with ImageQuant, release 3.2, software (both from Molecular Dynamics, Sunnyvale, CA). The total optical density of each dot was calculated according to Caciagli and Bosco (1). The square root of the total optical density of known amounts of TYLCV DNA was fitted to an asymmetric sigmoid curve (Gompertz curve), using the logarithm of DNA amounts as an independent variable. The fitted curve was used to calculate the DNA detected in each insect or insect part, taking advantage of the parallelism between the curves for TYLCV DNA in TE and of TYLCV DNA in insects (1). For each curve, the $C, D$, and upper discrimination limits (UDL) were calculated, using a $t$ value at the protection level of 0.05 for all limits. As defined by Fenlon and Sopp (7) for enzyme-linked immunosorbent assay tests and later extended to quantitative dot-blot hybridization assays (1), $C$ is the minimum true value of the difference between an unknown sample and the healthy control $\left(m_{x}-m_{h}\right)$ necessary to produce a response significantly different from that of the healthy controls; $D$, calculated from $C$, is the smallest true value of the difference $\left(m_{x}-m_{h}\right)$ that will be detected. The $D$ limit added to the response of the healthy control (in this case the lower asymptote of the asymmetric sigmoid curve) gives the minimum value of the response for which true detection, and hence quantification, can be claimed. The $U D L$ value, as defined in Caciagli and Bosco (1), is the maximum response that can be discriminated from the upper asymptote of the curve. Analysis of variance of fitted curves and residuals was as in Caciagli and Bosco (1). Only curves with more than $99 \%$ variance accounted for were used. In all cases, the $F$ test for the variance ratio of regression gave $P<0.001$. Insects having a quantifiable amount of TYLCV DNA hereafter are referred to as TYLCV-positive. Proportions of TYLCV-positive insects were compared by the Pearson chi-square test. Responses of insects below the limit of quantification are expressed in terms of the number of times the standard error of the response of nonviruliferous controls. Each membrane contained a subsample of each sample for a given experiment, including at least three nonviruliferous $B$. tabaci as negative controls.

\section{RESULTS}

Short AAP experiments. The results of the experiment with a 4-h AAP are shown in Figure 1. The distribution of detected TYLCV DNA levels did not vary, either in mean or shape, from the end of acquisition access up to $20 \mathrm{~h}$ later, both for the vector (Fig. 1A) and the nonvector, T. vaporariorum (Fig. 1B). A greater proportion of $T$. vaporariorum was TYLCV-positive than $B$. tab$a c i$, and the average amount of TYLCV DNA detected in $T$. va- porariorum at the end of acquisition was about 3.75 times higher than in B. tabaci.

The results of experiments with a12-h AAP are summarized in Figure 2. The mean amounts of TYLCV DNA detected in B. tab$a c i$ are shown for each sampling time, together with standard errors. There are no significant changes in the mean values from the end of the AAP up to $48 \mathrm{~h}$ later ( $P$ value of regression of $\log$ [picograms of DNA] against time $=0.838$ with $169 \mathrm{df})$ or in the proportions of TYLCV-positive insects $($ mean proportion $=$ $0.69 ; \chi^{2}=0.25$ with $3 \mathrm{df}$ ).
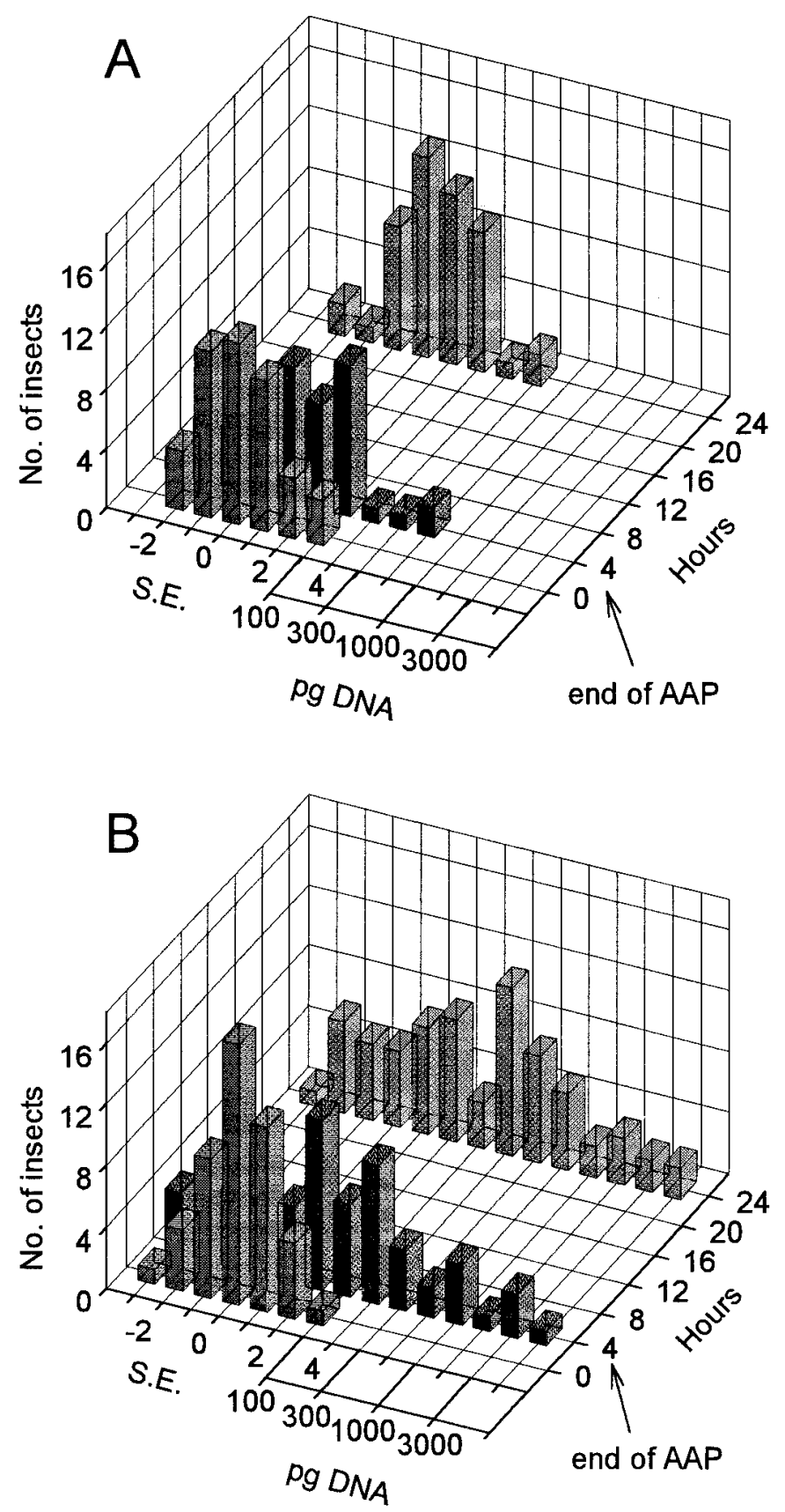

Fig. 1. 3-D histograms of tomato yellow leaf curl virus (TYLCV) DNA amounts (in picograms) detected in individual female A, Bemisia tabaci and B, Trialeurodes vaporariorum (a nonvector of TYLCV). Insects were allowed a 4$\mathrm{h}$ acquisition access period (AAP) on TYLCV-infected tomato plants and then were transferred to immune plants for $20 \mathrm{~h}$. The nonviruliferous controls are shown at time 0 . A standard error (SE) of the response for the nonviruliferous controls was calculated and used to divide both the controls and the insects with responses below the limit of quantification into classes. TYLCV DNA was quantifiable in insects with responses higher than 3.5 times the SE of nonviruliferous controls. 
Increasing AAP experiments. The proportion of TYLCV-positive insects increased with increasing AAP times, as did the average amount of DNA detected in these insects (Fig. 3). Only after a 24-h AAP was the population of TYLCV-positive insects clearly distinct from negative (background) values. At all other AAP times tested, some insects had response values between limits $C$ and $D$ (between $2.5 \times$ and $3.5 \times$ standard deviation of the healthy controls).

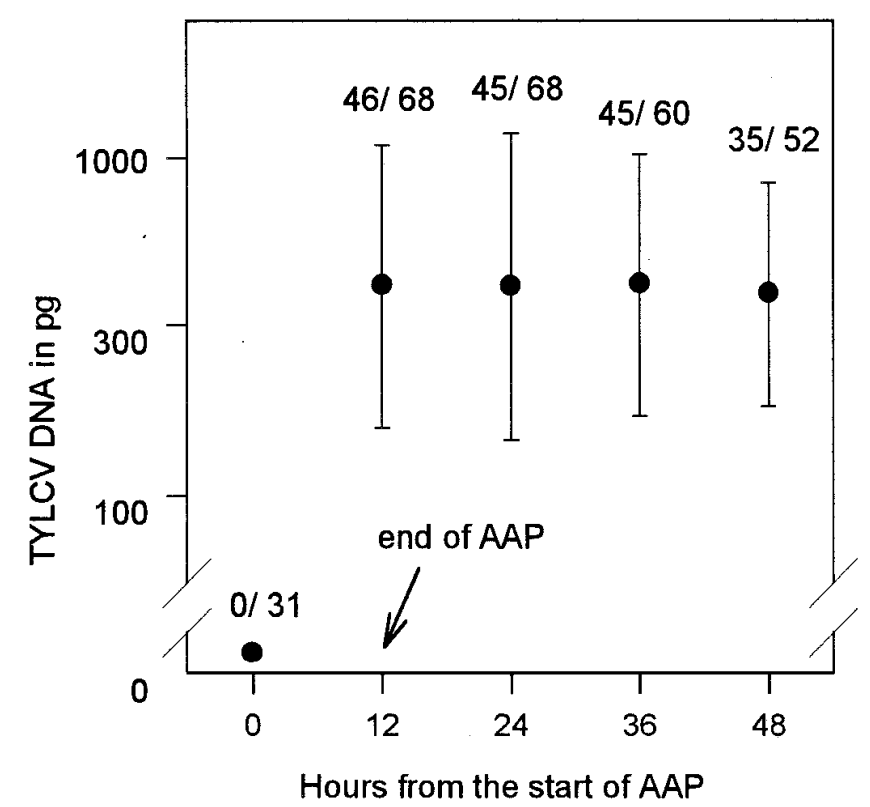

Fig. 2. Average amount $(\bullet)$ of tomato yellow leaf curl virus (TYLCV) DNA detected in individual female Bemisia tabaci at the end of a 12-h acquisition access period (AAP) on a TYLCV-infected tomato plant and after 12, 24, and $36 \mathrm{~h}$ on immune cucumber plants. Vertical bars represent standard errors. Numbers above each sampling time indicate the number of positive insects per number tested. An insect was considered positive when it had an amount of TYLCV DNA above the limit of quantification (about $60 \mathrm{pg}$ in the experiment shown).

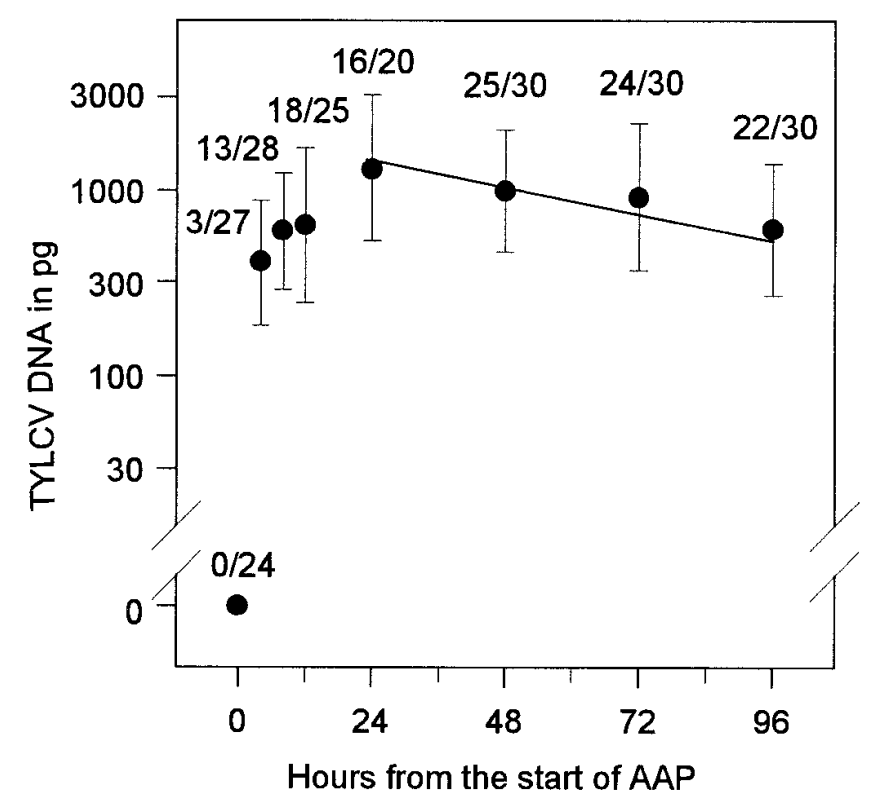

Fig. 3. Average amount $(\bullet)$ of tomato yellow leaf curl virus (TYLCV) DNA detected in individual female Bemisia tabaci after a 4-, 8-, 12-, or 24-h acquisition access period (AAP) on a TYLCV-infected tomato plant and after 24,48 , and $72 \mathrm{~h}$ of incubation on immune cucumber plants, following $24 \mathrm{~h}$ of AAP. Vertical bars represent standard errors, and the numbers above each sampling time are the number of positive insects per number tested. The line has been drawn according to linear regression of the individual values against time.
After the end of the AAP, the amount of viral DNA detected decreased significantly with time $(\log [$ picograms of DNA] $=-0.00422$ $\mathrm{h}+3.222 ; P$ value of regression $=0.009$ with $85 \mathrm{df}$ ); the proportion of TYLCV-positive insects did not vary significantly (mean proportion $=0.79 ; \chi^{2}=0.11$ with $3 \mathrm{df}$ ) between 24 and $96 \mathrm{~h}$ from the start of the AAP (Fig. 3).

The amount of viral DNA detected in positive insects increased further when the AAP was prolonged from 24 to $48 \mathrm{~h}$, although not at the same rate as from 16 to $24 \mathrm{~h}$ (Fig. 4). From the end of the AAP to day 22, detected DNA decreased significantly $(\log [$ picograms of DNA $]=-0.00069 \mathrm{~h}+2.8268 ; P$ value of regression $<0.001$ with $255 \mathrm{df}$ ). TYLCV DNA was detected in $B$. tabaci up to 20 days after the end of the AAP, without any significant change in the proportion of positive insects (mean proportion $=0.88 ; \chi^{2}=1.51$ with $10 \mathrm{df}$ ).

TYLCV DNA in dissected insects. At the end of the 24-h AAP, TYLCV DNA was detected in the abdomen (plus second and third thorax segments) of 10 of 14 insects $(71.4 \%)$; only 3 of these 10 insects were TYLCV-positive in the head (plus first thorax segment) $(3 / 14=21.4 \%)$. At day 2 after the start of the AAP, 11 of 15 insects $(73.3 \%)$ were positive in the abdomen, and 6 of these 11 insects $(40.0 \%)$ were positive in the head. These proportions did not change significantly over the times tested (mean proportion of insects positive in the abdomen per number tested $=0.74 ; \chi^{2}=$ 1.07 with $6 \mathrm{df}$; and mean proportion of insects positive in the head per number tested $=0.31 ; \chi^{2}=2.06$ with $6 \mathrm{df}$ ). Eighteen days after the end of the AAP TYLCV DNA was detected in the abdomen of 6 of 12 insects and in the head of 2 of these 6 . The total amount of TYLCV DNA detected in the head plus the abdomen did not differ from the amount detected in whole insects at comparable AAP times or after the end of the AAP. Of 98 insects tested (plus the 15 healthy controls) during the 19 days, only 1,14 days after the AAP, was positive in the head and negative in the abdomen. Two insects, one at day 1 and one at day 19, had response values between the $C$ and $D$ limits in both the head and abdomen, making it impossible to quantify the viral DNA.

\section{DISCUSSION}

Short AAP experiments showed there was no detectable increase of TYLCV DNA in insects within $48 \mathrm{~h}$ of the start of acquisition. The absence of any change in the distributions of TYLCV DNA amounts both in the vector, B. tabaci, and in the nonvector, T. va-

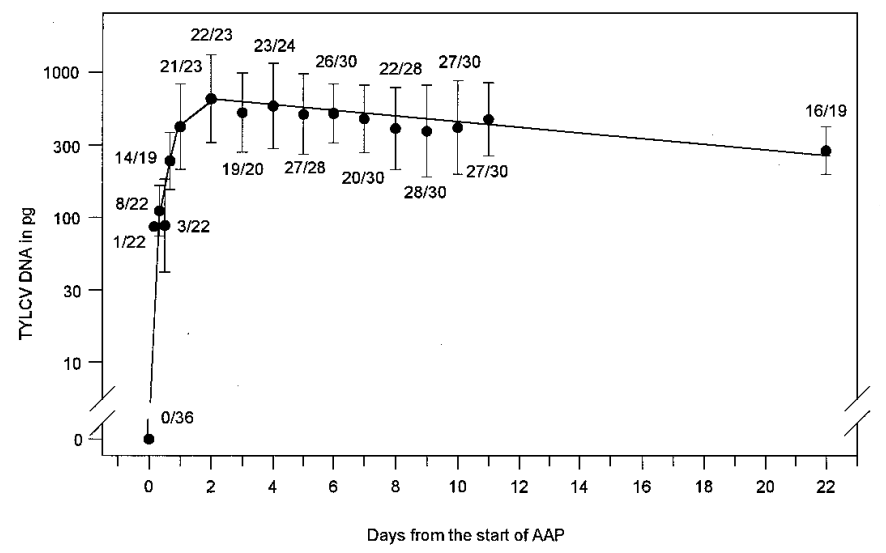

Fig. 4. Average amount (•) of tomato yellow leaf curl virus (TYLCV) DNA detected in individual female Bemisia tabaci after a 4-, 8-, 12-, 16-, 24-, or 48-h acquisition access period (AAP) on a TYLV-infected tomato plant and at different incubation times on immune cucumber plants, up to 20 days after the end of the 48-h AAP. Vertical bars represent standard errors, and the numbers above each sampling time are the numbers of positive insects per number tested. The line has been drawn according to linear regression of the individual values against time. 
porariorum, from the end of the 4-h AAP up to $20 \mathrm{~h}$ later (Fig. 1) indicates there was no increase in TYLCV DNA in either insect, not even from replicative forms of the virus possibly taken up from the host plant. There was no detectable increase of TYLCV DNA from the end of the 12-h AAP up to $36 \mathrm{~h}$ later based on the average amounts detected and the stable proportions of positive insects at each time tested (Fig. 2). Using a radioactive DNA-hybridization technique, Metha et al. (12) reported an increase of TYLCV DNA beginning immediately after the end of a 12-h AAP and lasting for about $100 \mathrm{~h}$. Data, expressed as counts per minute, were obtained by testing $B$. tabaci in groups of five in squash-blot assay.

Increasing AAP experiments, up to $48 \mathrm{~h}$, indicated an increase in TYLCV DNA with increasing AAP. Only after a 24-h AAP were there two well-separated populations of insects (those that had acquired enough TYLCV DNA to be quantified and those that had not), whereas at shorter AAP times these two populations overlapped. The amount of TYLCV DNA detected increased further when the AAP was prolonged from 24 to $48 \mathrm{~h}$ (Fig. 4), but the increment was less than between 16 and $24 \mathrm{~h}$. The kinetics of accumulation during acquisition based on measurements from single insects, i.e., TYLCV DNA increasing with length of AAP but at a decreasing rate after $24 \mathrm{~h}$ of acquisition access, agrees with that reported by Morin et al. (13) for B. tabaci tested in groups.

After the end of a 24- or 48-h AAP, the average amounts of TYLCV DNA detected decreased at an exponential rate (linear on the $\log$ scale). By day 22, it was reduced to less than half the original amount. Such a relatively slow rate of decrease was not detectable over a short time span, as from 12 to $48 \mathrm{~h}$.

No increase of TYLCV DNA content was detected in any experiment after the end of the AAP, whether it lasted 4, 12, 24, or $48 \mathrm{~h}$. Morin et al. (13), testing B. tabaci in groups of 20, reported an increase of TYLCV DNA from 10 to $20 \mathrm{~h}$ after a 1-h AAP, with a peak at $16 \mathrm{~h}$. Radiolabeled (newly synthesized) DNA followed a similar pattern, although delayed by $6 \mathrm{~h}$. TYLCV capsid protein began to accumulate after $10 \mathrm{~h}$ and increased almost linearly until $24 \mathrm{~h}$ (the longest time tested).

Our results do not exclude the possibility of replication of TYLCV in the vector, but if this occurs, it merely compensates for excretion and degradation within $36 \mathrm{~h}$ after a 12-h AAP, and it does not overcome the decrease of total DNA detected in insects after a 24- or 48-h AAP. Thus, if replication is involved, it either lasts for a short time or is slower than excretion and degradation. Variation in the amount of TYLCV DNA detected in whiteflies, within each acquisition or incubation time, makes it almost impossible to use models more complex than a simple exponential decrease that would allow discrimination between the possibilities of slow or brief replication or a combination of both.

There was no significant change in the proportion of TYLCVpositive insects from the end of the AAP to the last time tested. The same result was obtained with whiteflies tested after dissection. In both of the experiments with a 24-h AAP, the proportion of TYLCV-positive insects was higher than the proportion of infective insects obtained in previous experiments with the same AAP, virus isolate, and insect colonies (2). The proportion of insects that were TYLCV-positive in the head plus prothorax, and so, presumably, in the salivary glands, is closer to the proportion of transmitters reported for this particular combination of virus and vector (2). TYLCV DNA can still be detected well after infectivity is lost ( 7 days from the end of the AAP) (2), both in whole and dissected insects.

Notwithstanding the difference between the persistence of infectivity and detectability of the virus in the vector, we believe that the Sardinian isolate of TYLCV should continue to be prudentially classified as persistent and circulative in the vector, $B$. tabaci, rather than propagative.

\section{ACKNOWLEDGMENTS}

We thank G. P. Accotto for providing the plasmids needed to prepare the probes and D. Marian for skillful technical assistance.

\section{LITERATURE CITED}

1. Caciagli, P., and Bosco, D. 1996. Quantitative determination of tomato yellow leaf curl geminivirus DNA by chemiluminescent assay using digoxigenin-labeled probes. J. Virol. Methods 57:19-29.

2. Caciagli, P., Bosco, D., and Al-Bitar, L. 1995. Relationships of the Sardinian isolate of tomato yellow leaf curl geminivirus with its whitefly vector Bemisia tabaci Gen. Eur. J. Plant Pathol. 101:163-170.

3. Cohen, S., Duffus, J. E., Larsen, R. C., Liu, H.-Y., and Flock, R. A. 1983. Purification, serology, and vector relationships of squash leaf curl virus, a whitefly-transmitted geminivirus. Phytopathology 73:1669-1673.

4. Cohen, S., and Harpaz, I. 1964. Periodic, rather than continual acquisition of a new tomato virus by its vector, the tobacco whitefly (Bemisia tabaci Gennadius). Entomol. Exp. Appl. 7:155-166.

5. Crespi, S., Accotto, G. P., Caciagli, P., and Gronenborn, B. 1991. Use of digoxigenin-labelled probes for detection and host-range studies of tomato yellow leaf curl geminivirus. Res. Virol. 142:283-288.

6. Czosnek, H., Ber, R., Antignus, Y., Cohen, S., Navot, N., and Zamir, D. 1988. Isolation of tomato yellow leaf curl virus, a geminivirus. Phytopathology 78:508-512.

7. Fenlon, J. S., and Sopp, P. I. 1991. Some statistical considerations in the determination of thresholds in ELISA. Ann. Appl. Biol. 119:177-189.

8. Gallitelli, D., Luisoni, E., Martelli, G. P., Caciagli, P., Milne, R. G., Accotto, G. P., and Antignus, Y. 1991. L'accartocciamento fogliare giallo del pomodoro in Sardegna. Inf. Fitopatol. 61(7-8):42-46.

9. Harris, K. F., Pesic-Van Hesbroeck, Z., and Duffus, J. E. 1996. Morphology of the sweet potato whitefly, Bemisia tabaci (Homoptera, Aleyrodidae), relative to virus transmission. Zoomorphology 116:143-156.

10. Kheyr-Pour, A., Bendahname, M., Matzeit, V., Accotto, G. P., Crespi, S., and Gronenborn, B. 1991. Tomato yellow leaf curl is a whitefly transmitted monopartite geminivirus. Nucl. Acid Res. 19:6763-6769.

11. Luisoni, E., Milne, R. G., Caciagli, P., Accotto, G. P., Conti, M., Gallitelli, D., Martelli, G. P., Antignus, Y., Cohen, S., Marras, F., Idini, G., Loche, P., Piras, S., and Leoni, S. 1989. A geminivirus associated with a severe leaf curl disease of tomato in Sardinia. Pages 13-14 in: 6th Conf. Vegetable Viruses Working Group of ISHS, Asilomar, CA.

12. Metha, P., Wyman, J., Nakhla, M. K., and Maxwell, D. P. 1994. Transmission of tomato yellow leaf curl geminivirus by Bemisia tabaci (Homoptera: Aleyrodidae). J. Econ. Entomol. 87:1291-1297.

13. Morin, S., Zeidan, M., and Czosnek, H. 1995. Interactions between tomato yellow leaf curl geminivirus (TYLCV), the tomato host plant and the whitefly vector. Pages 85-88 in: Adv. Vegetable Virus Res. Proc. 8th Conf. Virus Dis. Vegetables, Prague.

14. Perring, T. M., Cooper, A. D., Rodriguez, R. J., Farrar, C. A., and Bellows, T. S., Jr. 1993. Identification of a whitefly species by genomic and behavioral studies. Science (Wash. DC) 259:74-77.

15. Pesic-Van Hesbroeck, Z., Harris, K. F., and Duffus, J. E. 1995. Bemisiageminivirus immunocytochemistry. Pages 89-92 in: Adv. Vegetable Virus Res. Proc. 8th Conf. Virus Dis. Vegetables, Prague. 